How to cite this article:

Sharma, I. (2019). Contexualising hate speech: A study of India and Malaysia. Journal of International Studies, 15, 133-144. https://doi.org/10.32890/jis2019.15.9

\title{
Contexualising Hate Speech: A Study of India and Malaysia
}

\author{
Ishita Sharma \\ University of Petroleum and Energy Studies, School of Law \\ Dehradun, Uttarakhand 248007, India \\ sharmaishita2011@gmail.com
}

DOI: https://doi.org/10.32890/jis2019.15.9

Received: 28/11/2019 Revised: $20 / 12 / 2019 \quad$ Accepted: 26/12/2019Ｐublished: 31/12/ 2019

\begin{abstract}
Hate speech is a verbal expression, which is designed to promote hatred based on race, religion, ethnicity and violence between different communities. Hate speech are systematically used to lash hatred towards minorities and for inflaming regional, religious and ethnic passion. It has been repeatedly observed that inflaming and deleterious words have been used by people of influence to further their vested interests and incite violence. Indian laws as well as Malaysian laws forbid anyone from making hate speeches that disturb the communal harmony and creates discord among the people. When the issue of suppression of hate speech comes to purview, the notion of reasonable restriction comes into picture. Consequent debate narrows down to two sharply contrasting opinions ie: restraints v. freedom of speech and expression. It is difficult to balance both divergent opinions. Article 19(1) of the Indian Constitution, provides for the freedom of speech and expression but also places reasonable restrictions under Article 19(2) on the grounds of public order, decency and morality. Similarly, Article 10 of the Malaysian Constitution empowers the Malaysian citizens with the freedom of speech and expression subject to restrictions imposed by the Parliament. Whenever these contradictory opinions are presented in front of the court, even the Apex court of the respective countries has shown its reluctance towards curbing such communally charged statements. Even if the judgment restraining hate speech is pronounced, it often comes too late, sometimes after the damage has already been inflicted, thus failing to exert any deterrent effect. By using doctrinal research methods, this paper a) discusses the terminology of hate speech; b) analyzes different legal provisions that deals with hate speech in India and Malaysia; and c) discusses non-legal solutions to the problem. This paper argues that although several legal provisions are available to curb hate speech, Alternative Dispute Resolution and counter speech may be used as alternative ways to address hate speech.
\end{abstract}


Keywords: Democracy, Freedom of Speech and Expression, Hatred, Hate Speech, Harmony.

\section{Introduction}

Like an unchecked cancer, hate corrodes the personality and eats away its vital unity. Hate destroys a man's sense of values and his objectivity. It causes him to describe the beautiful as ugly and the ugly as beautiful and to confuse the true with the false and the false with the true. ("Martin Luther King Jr. Quotes", n.d)

The term hate connotes an idea of something unpleasant. According to the Oxford English Dictionary, the term hate implies something towards which someone has a strong aversion to or dislike for or conjures a temperament of dislike (Lexico, 2019). By adding the term "speech" to the word, "hate" brings out a concept, which has held society in its grip throughout time, once a neologism a phenomenon that has crept into public discourse with an ease that the lexicon is no longer an uncharted territory but has become common parlance. Hate speech, composed of two very generic terms, hate and speech, in the eyes of a layman refers to words or connotations that have the potential of rousing one's emotions, feelings that are averse towards certain objects.

Hate Speech, as jargon is no longer a territory governed by the individuals of the legal world but within the grasp of the layman. Typing the term "hate speech" in the Google search bar on October 27, 2019, producedhas returnedas much as 154,000,000 results. A considerable portion of the results is indeed concerned with the legal aspects of the concept; it is an affront to the entrenched pristine ideals of freedom of speech and expression. At the same time, the results also comprised articles that discuss hate speech and its prevalence as an anathema that has entered society.

The author through doctrinal research methodology discusses a) the meaning of hate speech as a terminology b) analyses the legal provisions concerning hate speech in India and Malaysia and c) finally presents a solution to the problem that has become a trouble in the 21 st century.

\section{Hate Speech as a Terminology: Exploring the Contours}

Hate speech, which was once a neologism that entered the legal lexicon through the campus codes that were enforced in the United States of America (Heinze, 2013) and Mari Matsuda, for the first time used the term in her primary work, 'Public response to racist speech: Considering the victim's story' (Brown, 2017 ). Since then and now, it is akin to a virus that 
has contaminated almost every nation on this planet, and afflicted every legal system on this planet.

When it comes to hate speech, almost every nation has enacted laws in an effort to curb the same and the literature on hate speech has tried to unravel the concept in the light of the legalese that exists in relation to the same. But have we ever thought, is hate speech actually riddled with the notion of hate? Hate as already mentioned connotes something to which one has a strong aversion to or dislike for (Lexico, 2019). For instance, a man says that all meat eaters are sinners in the eyes of God. One glance at this statement will make an individual categorise it as hate speech. But does the utterance actually signal hate for meat eaters or simply a firm affirmation of one's religious ideals? This is the conundrum that hate speech faces, as not all utterances are riddled with hate. The author is nowhere trying to say that the connotation is a misnomer but is a conglomeration of various nuances that just cannot be strictly straitjacketed as hate, something which Alexander Brown (2017) calls a family resemblances concept, which will be discussed in detail in the forthcoming pages.

Every nation has in accordance with its system, enacted a set of legislations to tackle hate speech. For instance, England and Wales prohibits any form of incitement to hatred in its laws (Brown, 2017). Similarly, India and Malaysia has an umbrella set of provisions prohibiting some form of hate speech, although hate speech is nowhere defined in any of its laws. As mentioned earlier, the concept has at present, gone beyond the boundaries of hate as well as incitement or mere provocation as the legal concepts put it to be. It has now become something, which is used by everyone given the open access in the age of information technology, not just in the manner encapsulated in the legal world but in several kinds of contexts. Firstly, it is very pertinent to mention that a particular law that is in place is largely influenced by the historical contours and the societal set up in existence. Since it is a very well-known principle of jurisprudence that law is a manifestation of the society that exists at a point of time and it grows with the development of the society (Dhyani, 1985). Nevertheless, the legal concept of hate speech in various countries has been shaped by the historical factors and problems that plagued the various nations at that point of time. As far as the United States of America is concerned, racism brought this concept to the fore (Brown, 2017). Seeing the concept in the context of India and Malaysia, both are multi-ethnic, multireligious nations where the colours of diversity are widely celebrated and respected, the same diversity has also germinated in the form of a weed that is eating into the foundations of the respective nations (Patni \& Kaumudi, 2009).

Before going into the legal concept of hate speech in both the countries, it would be pertinent to mention that the term hate speech includes a diversity of concepts such as hate, hatred, contempt, hostility, enmity, inferiority, racist propaganda, xenophobia, anti-Semitism, group defamation, group vilification, insult, negative stereotyping, stigmatisation, humiliation, degradation, violation of dignity, discriminatory harassment, intolerance (Brown, 2017, p. 436). This shows that the evolution of the nature of the concept from being a mere portrayal 
of a feeling of aversion to embracing within itself a cluster of emotions that have certain common characteristics running through them. The first common thread that one can make out from these terminologies is that they are an affront to the dignity of an individual as being a part of a certain strata or identifiable group within the society. As Jeremy Waldron (2012) puts it that dignity is an immutable characteristic and this attack on dignity is not necessarily stemming primarily from an emotion of hate but also fear, condescension, insecurity, thus, making it clear that the phenomena is akin to a family of evils that come under the wider umbrella of hate. This can also be shown byFor example, a group of who were happily married men, walking on the street conversing with each other say that women as individuals must always be controlled in a way that they remain servile before men and their proper place is within the four walls of the house restricted to cooking and cleaning. As the men utter these words, it is clear that these utterances are not the manifestation of hatred for women as a gender but a result of negative stereotyping and condescension towards them. Thus, what the author is trying to bring across through this illustration is that hate speech as a concept has traversed the boundaries of hate and embraced several other characteristics within it.

The second common thread that runs is that they are directed towards a progeny that shares certain attributes among themselves. This group feels that certain words used concerning them shake the very foundations of their safe and secure standing in society which is an attack on the assurance of dignity (Waldron, 2012). For instance saying, all Muslims are terrorists and must be burned at the stakes is a direct attack on the dignified existence of Muslims as a community.

To summarize, hate speech can be broadly perceived as having the following characteristics, firstly, a remark that is an affront to the dignified existence of an individual. Secondly, the individual becomes a target as a result of his affinity with a group having certain distinct attributes. Thirdly, a family of concepts contribute to hate speech making it an equivocal phrase and not a univocal concept.

\section{Legal Provisions and Hate Speech}

After throwing light on the term hate speech, it is necessary now to come to the legalese associated with it. Laws normally function in tandem with the society in which they are framed. India, being a country, in the throes of colonialism and where history has had a chequered past wrought with communal tensions, hate speech is not defined anywhere and a perusal of the laws connected to the concept are vocal of India's colonial past. Relevant legal provisions (Law Commission of India, 2017, pp. 5-8) are as under: -

(i) The Indian Penal Code, 1860 (hereinafter IPC)

- Section 124A IPC penalises sedition

- Section 153A IPC penalises 'promotion of enmity between different groups 
on grounds of religion, race, place of birth, residence, language, etc., and doing acts prejudicial to maintenance of harmony'.

- Section 153B IPC penalises 'imputations, assertions prejudicial to nationalintegration'.

- Section 295A IPC penalises 'deliberate and malicious acts, intended to outrage religious feelings of any class by insulting its religion or religious beliefs'.

- Section 298 IPC penalises 'uttering, words, etc., with deliberate intent to wound the religious feelings of any person'.

- Section 505(1) and (2) IPC penalise publication or circulation of any statement, rumour or report causing public mischief and enmity, hatred or ill will between classes.

(ii) The Representation of the People Act, 1951

- Section 8 disqualifies a person from contesting elections if he is convicted for indulging in acts amounting to illegitimate use of freedom of speech and expression.

- Section 123(3A) and section 125 prohibits promotion of enmity on grounds of religion, race,caste, community or languageinconnection withelectionas acorrupt electoral practice and prohibits it.

(iii) The Protection of Civil Rights Act, 1955

- Section 7 penalises incitement to, and encouragement of untouchability through words, either spoken or written, or by signs or by visible representations or otherwise

(iv) The Religious Institutions (Prevention of Misuse) Act, 1988

- Section $3(\mathrm{~g})$ prohibits religious institution or its manager to allow the use of any premises belonging to, or under the control of, the institution for promoting or attempting to promote disharmony, feelings of enmity, hatred, ill-will between different religious, racial, language or regional groups or castes or communities.

(v) The Cable Television Network Regulation Act, 1995

- Sections 5 and 6 of the Act prohibit transmission or retransmission of a programme through cable network whichis deemed a contravenes the prescribed programme code or advertisement code. These codes have been defined in rule 6 and 7 respectively of the Cable Television Network Rules, 1994.

(vi) The Cinematograph Act, 1952

- Sections 4, 5B and 7 empower the Board of Film Certification to prohibit and regulate the screening of a film.

(vii) The Code of Criminal Procedure, 1973

- Section 95 empowers the State Government, to forfeit publications that are punishable under sections: 124A, 153A, 153B, 292, 293 or 295A IPC.

- Section 107 empowers the Executive Magistrate to prevent a person from committing a breach of the peace or disturbing public tranquillity or doing any wrongful act that may probably cause breach of the peace or disturb public tranquillity. 
- Section 144 empowers the District Magistrate, a sub-divisional Magistrate or any other Executive Magistrate specially empowered by the State Government on its behalf to issue orders in urgent cases of nuisance or apprehended danger. The above offences are cognizable or regarded as serious in nature. Thus, have serious impact on the freedom of citizens and empowers a police officer to arrest without orders from a magistrate and without a warrant as in section $155 \mathrm{CrPC}$.

After a perusal of the offences listed in different enactments that are connected with hate speech, one can easily come to the inference that a parameter of incitement runs through the existing literature of laws on the premise of fuelling enmity, disharmony, ill-will, hatred, all of which are synonyms of hate speech. Hate speech is like a wide canopy that has in its folds several kinds of phenomena that attack the dignity of an individual, leaving those boundaries untouched by the legal paradigms which isare shown in subsequent paragraphs.

Several instances may substantiate this point and bring out the lacunae in the existing body of laws, which primarily focuses on incitement, intent and hatred. Recently in an interview with the increasing spate of rapes in the country, a lawmaker belonging to a national party of India, remarked, "Women should not venture out with men who are not relatives" (Neelakanta, 2016). Another instance where the Prime Minister of the country i.e. India found himself embroiled in a controversy when he remarked at a lecture in Dhaka University in Bangladesh in a reference to the Bangladesh Prime Minister, Sheikh Hasina, "Boldly saying that she has zero tolerance towards terrorism, despite being a woman" (Verma, 2017). Another famous Indian politician, while speaking out against the imposition of the death penalty on a certain rape accused commented, "Boys will be boys, they commit mistakes." Further, added that girls intermingling with boys is the reason that rapes are committed (Verma, 2017).

The above-mentioned statements are clearly an affront to the dignity of the groups lashed out against, i.e. women and do not smack of hatred or enmity of any kind but at the same time are highly divisive in nature. The question arises as to whether the laws are sufficient to bring them within the ambit of hate speech since these do not fulfil any of the parameters outlined in the enactments mentioned. This includesis coded speech (Lepoutre, 2017), which the current provisions fail to address. To illustrate, in an election rally held in February 2017 in Fatehpur, Uttar Pradesh, Prime Minister Modi said, "If there is a cemetery in the village, there should be a crematorium as well; if there is electricity in Ramzan, it should be there oin Diwali as well; there shouldn't be any discrimination." (Jaiswal, Jain \& Singh, 2018). The statement, on the face of it and going by the legal concept of hate speech is harmless but going by the diverse multicultural society of India, it is highly divisive in nature. To cite another example, in the same election campaign, Amit Shah commented, "If by any mistake, BJP loses, the victory and defeat may be in Bihar but fire crackers will go off in Pakistan" (Jaiswal and et al. 2018). Now such inflaming statements garbed in coded words coming from people of immense influence at the time of elections are bound to cause deep fissures in the multicultural country and this acknowledgement is the need of the hour.

Comparatively, Malaysia, a democratic country akin to India but much smaller in size, also do not define hate speech in any particular provision but deals with it indirectly under existing 
laws. The Malaysian Penal Code, the Multimedia and Ccommunications and Multimedia Act of 1998 and the Sedition Act of 1948 indirectly deal with provisions relating to the same indirectlythe matter at hand. The major lacunae despite the presence of relevant laws is that Malaysia has not ratified treaties that deal with hate speech. The International Covenant on Civil and Political Rights under Article 20(2) and the International Convention on the Elimination of All Forms of Racial Discrimination under Article 4(a) deal with hate speech (Salleh Buang, 2019). Apart from the Malaysian Penal Code, under Section 503 to 505 as well as Section 298A of, the Sedition Act and section 233 of the Communications and Multimedia Act, 1998 deal with the issue indirectly. According to S. 298A of the Sedition Act, it is an offence to create disharmony, disunity or enmity on the grounds of religion. The purpose of S.298A is to maintain amicability between persons of different religions by not allowing anyone to act in a manner that would adversely affect any of the interests that the law is meant to preserve. This covers the ambit of hate sepeech. However, the maximum penalty under this section is only 5 years. While the author is not suggesting that restrictions on speech should be stricter, it is important to look into the background of the said words. The provided punishments should range from light to more serious so that the sentence handed out would be commensurate with the crime committed, depending on the circumstances, which one or two sections in the Penal Code cannot appropriately address. As Malaysia is a country where religion as well as race are sensitive issues, there is a need to revisit the laws under the Penal Code, by way of introducing categories such as race, religion, gender, caste, and make the laws more refined and clearer.

To illustrate this point further, the most recent instance is that of the Seafield temple controversy, the aftermath of which has led to demands even from Malaysian lawmakers to have more proper and well-delineated provisions pertaining to hate speech (FMT Reporters, 2019). Batu Kawan MP Kasthuri Patto, also exhorted the government to lay down a stricter and a more effective regulatory regime as far as hate speech is concerned in the wake of the Seafield temple controversy and death of a transgender woman in Klang. To quote, "In Malaysia, we do not have a specific law to regulate or criminalise hate speech, especially against ethnicities and religious groups or even gender." Adding further, "The recent saga that unfolded over the Seafield Mariamman temple land dispute and its quick escalation into a racial and religious matter is evidence of how easily a matter can morph and transgress into a racial and religious (issue) in a violent manner" (FMT Reporters, 2019). These words clearly depict the urgency of having proper laws on hate speech in the country and how situations show that even the small island nation has been plagued by the menace in its own way.

Another recent example is the case of Zakir Naik, where several ministers have demanded his expulsion in the light of his incendiary statements such as "Malaysian Hindus are more loyal to Indian premier Narendra Modi than to Mahathir" (Genevleve Chla, 2019). Such divisive statements have the potential of creating immense unrest.

There have been efforts as well as political will to shed the weight of blame pertaining to chilling free speech through change in the existing legalese via the Sedition (Amendment) Act of 2015 which has repealed the provision that talked of sedition against the government. 
Further more, in October 2018, the Communications and Multimedia Minister, Gobind Singh Deo announced that the cabinet had agreed to a moratorium on the use of the Sedition Act pending its repeal, but this moratorium was lifted a month later following the clashes surrounding a Hindu temple in Subang Jaya, and unsavoury comments made towardson the Malaysian monarchy (Fauzi, 2019).

Recently, Prime Minister Tun Dr Mahathir Mohammed announced that his government will introduce legislation to replace the Sedition Act. However, the contours of this proposed legislation has yet to be disclosed.

Thus, a serious lacunae also emerges in Malaysian laws where there is a direct need to introduce a more stricter regime by introducing wider laws in the sense that instead of repercussions on public order being the sole criterion, factors such as gender, race, religion, caste, sex, be singled out to frame a law where there are attacks perceived to be an affront to their dignity as can be seen from the aforementioned examples. After an analysis of the laws in the respective countries, in the next section the author tries to present a solution to the problem.

\section{Hate Speech and Way Ahead}

Several ways may be used as solutions to counter hate speech. The following artistic depiction by Joe Sacco, in the Guardian newspaper, summarises a very balanced response to this response on the menace of the attack on December 7, 2015 at the headquarters of Charlie Hebdo, a weekly magazine in France (Sacco, 2015).

The first unique feature of this illustration is that it succinctly depicts the fact that there are always two sides to an issue, where there is a direct friction between them and an affront to one another. Second, it points to the fact that in a society where dignity is a priceless virtue, there must be space for all kinds of views to bloom even if they are repulsive in nature. Finally, it calls for a vocal space for both the parties where repulsive views are admonished but at the same time the contextual basis of those views is acknowledged and the reason it appeals to the masses is sought. 

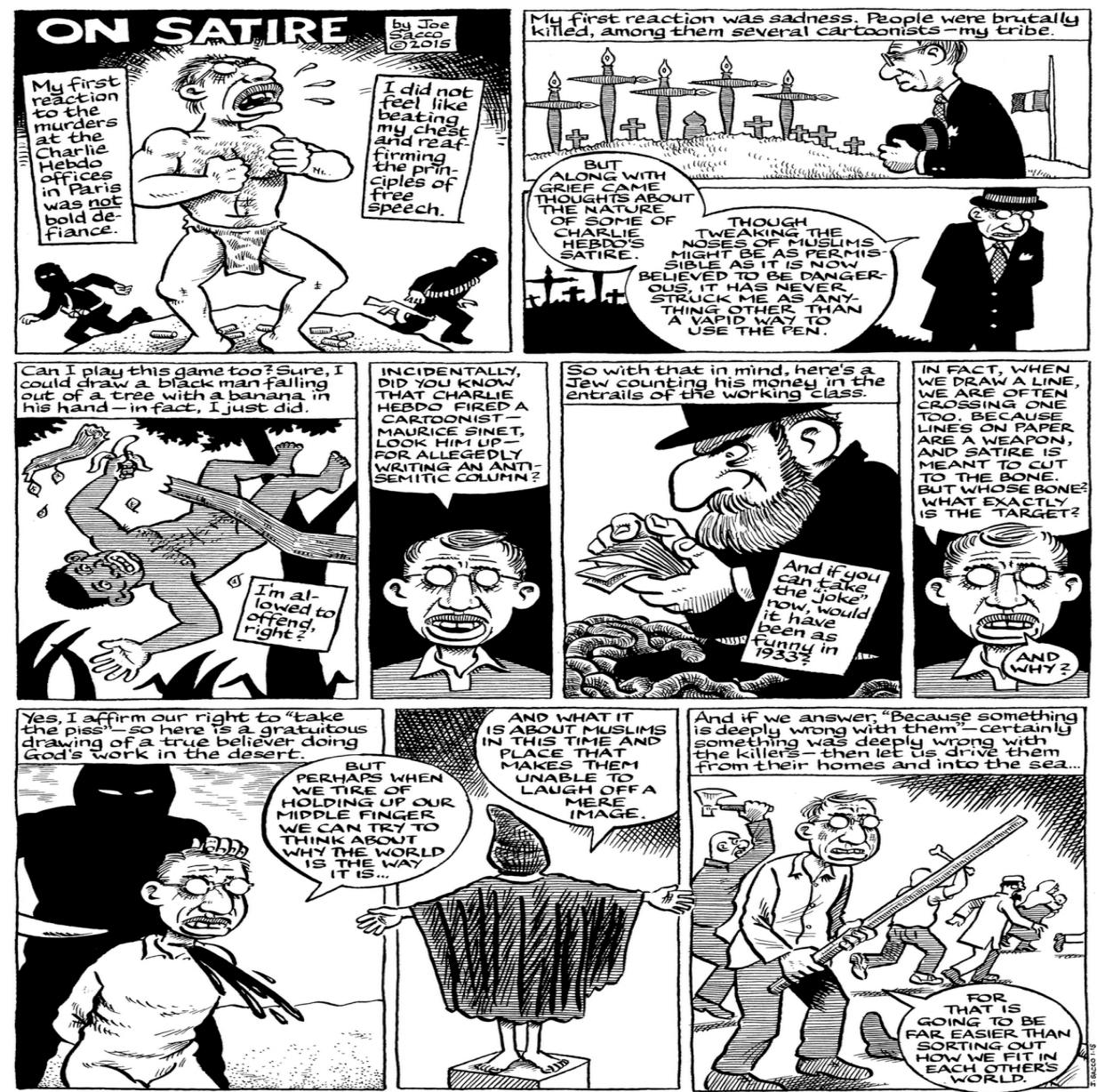

Source: "On Satire" was first published on the Guardian website. Joe Sacco, "On Satire", The Guardian, 2015, Courtesy of Guardian News \& Media Ltd at https://www.theguardian.com/world/ ng-interactive/2015/jan/09/joe-sacco-on-satire-a-response-to-the-attacks.

Apart from the criminal framework in existence to fight the menace, several non-legal measures can also be taken to tackle the problem. This includes counter speech, alternative dispute resolution mechanism as prevalent in Australia, as well as certain strategies as endorsed by the Law Commission of India which are deemed pertinent in view of the peculiar demography of both these countries such as:

- Use of television to bring across the message of harmony among communities,

- Influential figureheads of religion, widely respected to spread and harbour the message of harmony among communities

- Social media intermediaries to become more vigilant in the content that they disseminate

- Sensitisation of the masses to stop the spread of rumours and hateful messages. 
These non-legal measures if implemented with sincerity can go a long way in curbing the menace.

Alternative dispute resolution is a mechanism where the differences between the parties are settled by way of mediation, negotiation and arbitration. It embraces a victim centric approach to justice. It has served as an effective mechanism in the dispensation of justice in the sense that it provides for a novel approach of victim-offender reconciliation, recuperating the victim and at the same time a chance to start afresh for the offender, the basis of restorative justice. Secondly, the outcome to be achieved can be safely tailored according to the condition of the victims within the ambit of the law. Thirdly, it is a cost and time effective mechanism for the settlement of disputes between parties as compared to normal court procedure.

As far as this mechanism is concerned, its successful implementation in cases of hate speech has been witnessed in Australia (Gelber, 2012). Such recourse to a civil remedy rather than criminal has been found to be an effective way to tackle the menace. as also available in the form of statistics from a study that less than 200 complaints were registered in the decade spanning from 1990 to 2010 where the average number of complaints was 4000 (Gelber $\&$ McNamara, 2014). Out of these, only a mere $2 \%$ went to court and the rest were settled amicably through the mentioned procedure. This is an example of community advocacy where the perpetrator is asked to apologize to the victim or else face heavy monetary penalties (Gelber \& McNamara, 2015).

Finally, counter speech is a response to incendiary words with the aim of extricating the damage inflicted on the victim. The embrace of such a mechanism especially by political elites, people of influence, and public officials who hold official power can go a long way in mitigating harm to the dignity of the victims. In criticizing the speakers of hate speech, the state through its officials is taking a firm stand against them, instilling confidence and reassurance in its victims. The state is in a way saying, "We are deeply apologetic of what happened but you are not alone. You are not outliers and what has been spoken are empty words of no substance."

This can be illustrated through the response of Christaine Taubira, the then French Minister for Justice who intercepted in a response to David Rachline (a French National Senator) in the French Senate who criticized her after she exhorted for humane treatment of criminals by calling them, "thugs" and "executioners" (Lepoutre, 2017). Taubira replied that such scapegoating and exclusionary attempts towards polarisation will be fought with full power. Such a response garnered a standing ovation from the French Senate as well. This shows how the weapon of counter speech especially by public officials can reinstall lost confidence and faith of the victims.

Apart from direct counter speech, the state can use other methods such as supporting activists who vehemently decry such activities, proper public education as well as programmes specially designed to educate on democratic values. 
In short, apart from legal measures which are the prime prerogative of the state, solutions through non legal measures may also serve as a potent tool in curbing the menace of hate speech in democracies like India and Malaysia, where restrictions on speech are seen as an affront on the freedom of speech and expression. In the words of Justice Oliver Wendell Holmes, a democracy must be a free market place of ideas. The recourse to such measures does not stifle the well enshrined virtues of free speech for-

'Democracy thrives on disagreements provided they do not cross the boundaries of civil discourse.'(Anonymous)

\section{References}

Brown, A. (2017). What is hate speech? Part- I: The myth of hate. Law and Philosophy, 36(5), 561-613. Doi 10.1007/s10982-017-9300-x.

Brown, A. (2017). What is hate speech? Part- I: The myth of hate. Law and Philosophy, 36(4), 419-468. Doi 10.1007/s10982-017-9297-1.

Chla, R. (2019). Zakir Naik's deportation debate: Here's a timeline of everything that has happened. Retrieved from https://www.businessinsider.my/zakir-naiks-deportationdebate-heres-a-timeline-of-everything-that-has-happened/

FMT Reporters. (2019). Criminalise hate speech, MP says after Seafield fiasco, transgender deaths. Retrieved from https:/www.freemalaysiatoday.com/category/ nation/2019/01/04/criminalise-hate-speech-mp-says-after-seafield-fiascotransgender-deaths/

Gelber, K., \& McNamara, L. (2014). Explainer: How do Australia's laws on hate speech work in practice”. The Conversation. Retrieved from https://theconversation.com/ explainer-how-do-australias-lawson-hate-speech-work-in-practice-26105

Gelber, K. (2012). Reconceptualizing counterspeech in hate-speech policy (with a focus on Australia). In M. Herz (Eds.), The content and context of hate speech: Rethinking regulation and responses. Cambridge: Cambridge University Press.

Jaiswal, N., \& Jain, S. (2018). Under Modi government, VIP hate speech skyrockets - By $500 \%$. Retrieved from https:/www.ndtv.com/india-news/under-narendra-modigovernment-vip-hate-speech-skyrockets-by-500-1838925

Law Commission of India. (2017). Report 267: Hate speech. Retrieved from http:// lawcommissionofindia.nic.in/reports/Report267.pdf

Lepoutre, M. (2017). Hate speech in public discourse: Apessimistic defense of counterspeech. Social Theory \& Practice, 43(4), 851-883. Retrieved from https://www.jstor.org/ stable/26405309.

Patni, R., \& Kaumudi, K. (2009). Regulation of hate speech. NUJS Law Review, 749(2), 749-777. Retrieved from nujslawreview.org/wp-content/uploads/2018/12/ritikapatni.pdf.

Penal Code. (2015). Laws of Malaysia. Retrieved from http:/www.agc.gov.my/agcportal/ uploads/files/Publications/LOM/EN/Penal\%20Code\%20\%5BAct\%20574\%5D2.pdf 
Sacco, J. (2015). On Satire - a response to the Charlie Hebdo attacks (Comic Strip). Retrieved from https://www.theguardian.com/world/ng-interactive/2015/jan/09/joesacco-on-satire-a-response-to-the-attacks

Verma, A. (2017). 10 Bizarre Statements made by Indian politicians that will make you facepalm hard. Retrieved from https://www.news18.com/news/politics/10-bizarrestatements-made-by-indian-politicians-that-will-make-you-facepalm-hard-1481489. html

Waldron, J. (2012). The harm in hate speech. Cambridge, Massachusetts; London, England: Harvard University Press. Retrieved from http://www.jstor.org/stable/j.ctt2jbrjd

Yadav, A. (2018). Countering hate speech in India: Looking for answers beyond the Law. ILI Law Review, Winter Issue (2). Retrieved from ili.ac.in/pdf/csi.pdf. 